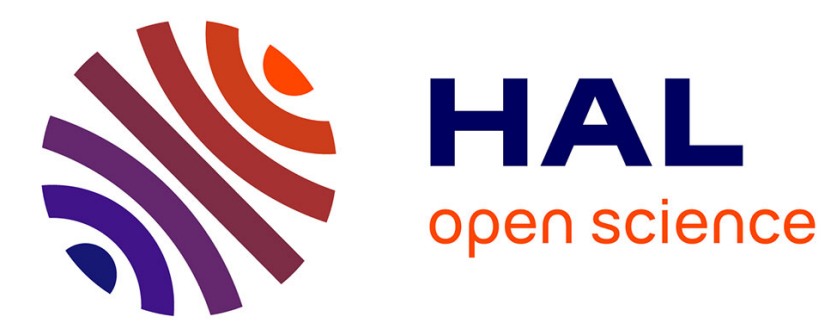

\title{
Deep structure, recent deformation and analog modeling of the Gulf of Cadiz accretionary wedge: Implications for the 1755 Lisbon earthquake
}

\author{
Marc-André M-A Gutscher, Stephane Dominguez, Graham K. Westbrook, \\ Pascal Leroy
}

\section{To cite this version:}

Marc-André M-A Gutscher, Stephane Dominguez, Graham K. Westbrook, Pascal Leroy. Deep structure, recent deformation and analog modeling of the Gulf of Cadiz accretionary wedge: Implications for the 1755 Lisbon earthquake. Tectonophysics, 2009, 475 (1), pp.85-97. 10.1016/j.tecto.2008.11.031 . hal-00424922

\section{HAL Id: hal-00424922 \\ https://hal.univ-brest.fr/hal-00424922}

Submitted on 19 Oct 2009

HAL is a multi-disciplinary open access archive for the deposit and dissemination of scientific research documents, whether they are published or not. The documents may come from teaching and research institutions in France or abroad, or from public or private research centers.
L'archive ouverte pluridisciplinaire HAL, est destinée au dépôt et à la diffusion de documents scientifiques de niveau recherche, publiés ou non, émanant des établissements d'enseignement et de recherche français ou étrangers, des laboratoires publics ou privés. 


\title{
Deep structure, recent deformation and analog modeling of the Gulf of Cadiz accretionary wedge: implications for the 1755 Lisbon earthquake
}

\author{
MS for Special volume of Tectonophysics, Proceedings of the MAPG Meeting Marrakech \\ (revised version returned 15 Oct. 2008)
}

Gutscher, Marc-André (Université Européene de Bretagne, Brest, IUEM, Domaines Océaniques, UMR6538 CNRS, Univ. Brest, France),

Dominguez, Stephane (Univ. Montpellier II, Géosciences Montpellier, UMR5243 CNRS, Montpellier, France),

Westbrook, Graham K. (Univ. Birmingham, United Kingdom),

Leroy, Pascal (Université Européene de Bretagne, Brest, IUEM, Domaines Océaniques, UMR6538

CNRS, Univ. Brest, France),

Corresponding author: M-A Gutscher, e-mail: gutscher@univ-brest.fr

Phone: [+33] (0)2 98498727

Fax: [+33](0)2 98498760

\begin{abstract}
:
The Gulf of Cadiz spans the plate boundary between Africa and Eurasia west of the Betic-Rif mountain belt. A narrow east dipping subduction zone descends beneath the Gulf of Cadiz and the straits of Gibraltar. The deep crustal structure of the Gulf and the adjacent SW Iberian and Moroccan margins is constrained by numerous multi-channel seismic reflection and wide-angle seismic surveys. A compilation of these existing studies is presented in the form of depth to basement, sediment thickness, depth to Moho and crustal thickness maps. These structural maps image an E-W trending trough, with thin $(<10 \mathrm{~km})$ crust beneath the Gulf of Cadiz. This trough is filled by an eastward thickening wedge of sediments, reaching a thickness of $10-15 \mathrm{~km}$ in the eastern Gulf. These sediments are tectonically deformed, primarily along a series of westward-vergent thrust faults and represent a 200-250 km wide accretionary wedge. The northern and especially the southern limits of the accretionary wedge are marked by sharp morphological lineaments showing evidence of recent deformation. These tectonic limits are situated in an internal position with respect to the Miocene deformation front (external Betic and Rif allocthons), which has been abandoned. At the western boundary of the accretionary wedge, near the adjacent Seine and Horseshoe abyssal plains, an E-W trending basement high (Coral Patch Ridge) can be seen indenting the deformation front in an asymmetric manner. Analog modeling is performed using granular materials accreted against a semicircular backstop (representing the basement of the Rif aand Betic mountain belts). The modeling initially produces a symmetric, arcuate accretionary wedge. The ensuing collision of an oblique rigid indenter retards accretion on one side, resulting in an embayment and a locally steeper deformation front. The deformation pattern observed in morphology and high-resolution seismic profiles suggests the accretionary wedge and underlying subduction system is still active. The implications of active subduction for the source region of the 1755 Lisbon earthquake and the regional seismic hazard assessment are discussed.
\end{abstract}


Keywords: Iberia, Morocco, accretionary wedge, crustal structure, active faults

Introduction

The Gulf of Cadiz is located offshore Southwest Iberia and Northwest Morocco just west of the Betic-Rif mountain belt and astride the Africa - Eurasia plate boundary. However, the nature and exact location of the plate boundary here is uncertain, due to a broad region of complex deformation and diffuse seismicity roughly $200 \mathrm{~km}$ wide, from north to south (Sartori et al ., 1994; Tortella et al., 1997; Jimenez-Munt et al., 2001) (Fig. 1). Two types of geodynamic models have been proposed to explain the recent tectonics and formation of this region; models involoving delamination of continental lithosphere beneath the Betic-Rif Alboran Sea region (Platt and Vissers, 1989; Calvert et al., 2000), and those including subduction of oceanic lithosphere, with associated roll-back (Lonergan and White, 1997; Gutscher et al., 2002; Duggen et al., 2004). Tomographic data image an east-dipping slab of cold, dense lithosphere extending continuously from the Atlantic domain of the Gulf of Cadiz to the $660 \mathrm{~km}$ discontinuity beneath the Alboran Sea (Gutscher et al., 2002; Spakman and Wortel, 2004). A recent study which examined the dispersion of teleseismic body waves concluded that this east dipping slab of dense lithosphere was oceanic in nature, thus supporting the subduction model and effectively ruling out the delamination model (Bokelmann and Maufroy, 2007). Seismic reflection and refraction profiles image a gently eastward dipping basement and eastward dipping decollement beneath a thick pile $(>6 \mathrm{~km})$ of deformed sediments which was interpreted to be an accretionary wedge, related the east-dipping subduction zone beneath the Cadiz-Gibraltar region (Gutscher et al., 2002; Thiebot and Gutscher, 2006). GPS data reveal the presence of a west to southwestward moving tectonic block in the Betic-Rif-Alboran region (Stich et al., 2007; Tahayt et al., 2008), which has been alternatively interpreted as being related to subduction roll-back (Fernandes et al., 2007) or as roll-back linked to delamination (Fadil et al., 2006).

The Gulf of Cadiz region has experienced strong instrumental earthquakes like the 1969 M7.9 Cape St. Vincent earthquake (Fukao, 1973), the 1964 M6.5 Huelva earthquake and the recent 12 Feb. 2007 M6.0 Cape St. Vincent earthquake (Stich et al. 2007). The strongest earthquake in European history struck offshore SW Iberia in 1755, the M8.7 Great Lisbon earthquake (Martinez-Solares et al., 1979; Johnston, 1996), though the location of the source remains controversial (Zitellini et al., 2001; Terrinha et al., 2003; Gracia et al., 2003a; Gutscher, 2004). During the past decade, many marine geophysical studies have been performed in the region in an effort to identify the source region of the 
1755 earthquake and to obtain better estimates on the long-term frequency of such high magnitude events. An accurate inventory of the active faults in the area can make a significant contribution to improving long-term seismic hazard assessments for the region. The purpose of this study is to present the state of the art on the deep crustal structure of the region as well as examine the shallow morphology. These observations will be related to the recent and ongoing tectonics in the area in an effort to answer the question whether subduction is still active and poses significant seismic hazard to the region.

Data

Seafloor bathymetry

As a result of numerous marine geophysical surveys performed since the year 2000, the majority of the Gulf of Cadiz region has been covered by multi-beam swath-mapping. The bathymetric compilation presented here (Fig. 2) incorporates data from the following surveys; Cadisar, Cadisar2, TV-GIB and DelSis (all using the R/V Suroit EM300 system), the Delila and MatesPro cruises (with the NRP Dom Carlos EM120 system), the GAP cruise (R/V Sonne EM120 system) and a transit performed by the R/V Marion Dufresne following the Microsystems Cruise. The Marion Dufresne data were processed by X. Morin. Additional bathymetric data were provided by D. Masson and C. Berndt from the 2006 Hermes Cruise onboard the R/V Charles Darwin. The R/V Suroit data from the Cadisar (Mulder et al., 2003) and Cadisar2 (Mulder et al., 2006) cruises were processed with Caraibes software (developed by Ifremer) and typically have a spatial resolution better than $30 \mathrm{~m}$ (in water depths $<2000 \mathrm{~m}$ ). The MatesPro data (Terrinha et al., in press) were processed by the Portuguese Instituto Hidrografico Team. The GAP bathymetric data (Kopf et al., 2003) in the SE portion of the Gulf of Cadiz were processed using Caraibes software and included in this compilation for areas not mapped by the Cadisar or Delila surveys.

The bathymetric map (Fig. 2A) reveals several distinct morphological provinces. These include, the flat and nearly featureless abyssal plains, bounded by generally E-W to N60E trending basement highs and by the adjacent continental margins. The southern Portuguese (Algarve) margin is steep and deeply incised by S to SW draining canyons. The SW Spanish margin is much flatter and marked by diverse sedimentary structures, (a contourite levee with accompanying channels, contourite drift, seafloor sand-dunes, etc.) formed as the Mediterranean Outflow Water locally erodes and redeposits large quantities of sediment (Mulder et al., 2003; 2006). The most prominent feature however, is a region of gently undulating morphology with elongate curvi-linear ridges and troughs (Fig. 2B). This gently inclined slope $\left(1^{\circ}\right.$ westward dip on average) forms the surface of a sediment pile with a relatively high rugosity (compared to the abyssal plain regions). The deformed sedimentary slope is bounded by a continuous, horseshoe-shaped deformation front between 300 and $400 \mathrm{~km}$ in 
total length. The southern boundary is particularly sharp, and forms an E-W lineament off the Moroccan margin at the northern limit of the Rharb submarine valley.

Seismic images of the deformation front

Deep sounding seismic data have been acquired in the Gulf of Cadiz imaging the deformation front and internal portions of the deformed sediment slope, in particular the Sismar 360-channel seismic data acquired by the R/V Nadir in April 2001 (Gutscher et al., 2002, Thiebot and Gutscher, 2006) and 24-channel seismic data acquired by the R/V Suroit in April 2005 during the DelSis cruise (Gutscher et al., 2008). These data image the sediment slope to be an eastward thickening pile of sediment, with strong internal deformation, overlying a region of sub-horizontal to gently east dipping reflectors (separated by a thin decollement layer). West vergent ramp thrusts are observed soling out to this decollement. The seismic data clearly demonstrate that the base of the accretionary wedge (the decollement and top basement reflectors) is eastward dipping and therefore that the wedge has a primarily tectonic origin (Gutscher et al., 2002) and is not a large-scale gravitational feature. At a more shallow level $(<2000 \mathrm{~m}$ water depth in the easternmost portion of the wedge) some superficial gravity sliding is occurring, likely along rheologically weak layers (highly overpressured shales or evaporates) (Maestro et al., 2003; Medialdea et al., 2004; Gutscher et al., 2008). The majority of the accretionary wedge was constructed by offscraping of deep sea sediments during Miocene (and earlier) westward motion of the Gibraltar arc (Thiebot and Gutscher, 2006; Iribarren et al., 2007). There is still ongoing debate as to the current day activity of the system. Deep seismic profiles BS1 and GC3 on the SW Spanish margin image deformation of shallow sedimentary layers to the SW of the Guadalquivir river (due W of the city of Cadiz) (Gracia et al., 2003b) at the NE lateral boundary of the accretionary wedge. Here we present some high resolution Chirp profiles acquired by the R/V Suroit during the DelSis cruise which document recent deformation in the uppermost sedimentary layers at the western and southeastern lateral boundaries of the accretionary wedge.

Chirp profile 19 crosses the NW deformation front at the eastern termination of the Horseshoe abyssal plain (Fig. 3A). The highly reflective, sub-horizontal turbiditic sediments, associated with the abyssal plain can be clearly seen to the NW. The nature of the sediments was confirmed by gravity coring at the NW end of the profile, which revealed alternating fine clay hemipelagic sediments, and turbiditic sequences grading downwards from fine to coarse grained (sandy) layers (Babbonneau, et al., 2006). There is an abrupt change in slope at the deformation front and further SE the sedimentary strata are less reflective and gently folded, rising to form an undulating slope on the sea-floor. The sediment thickness varies between the minor sub-basins in the troughs and on the crests of the anticlinal ridges, suggesting a syn-tectonic sedimentation pattern (Fig. 3A).

Some of the best structural images were obtained from the shallow water Eastern Rharb Valley 
( $<1600 \mathrm{~m}$ depth). Two spectacular images of surface and shallow subsurface deformation at the seafloor are shown below crossing the northern edge of the Rharb marine valley (the southern limit of the accretionary wedge) (Figs. $3 \mathrm{~B}, \mathrm{C}$ ). The former is in water depths of roughly 500-600 $\mathrm{m}$ and shows folds associated with faults which emerge at the seafloor (Fig. 3B). The latter is on the shallow NW Moroccan continental platform in water depths between $100 \mathrm{~m}$ and $150 \mathrm{~m}$. Here subvertical faults can be seen, most of which are truncated by a major horizontal unconformity. This unconformity is at about $120 \mathrm{~m}$ water depth and corresponds to the sea-level lowstand during the last glacial maximum (LGM) at about $20 \mathrm{ka}$. The LGM unconformity is gently folded in places and slightly offset by a fault, indicating recent deformation (post dating $20 \mathrm{ka}$ ) (Fig. 3C). This provides definitive proof that active deformation occurs on the SE flank of the accretionary wedge.

A 24-channel seismic profile acquired by the R/V Suroit (DelSis cruise) in April 2005 crosses the entire Rharb submarine valley at $2800 \mathrm{~m}$ water depth and provides additional constraints on the timing of deformation on the southern flank of the accretionary wedge (Fig. 4). At the base a thrust anticline is imaged, which may represents the early Miocene thrust wedge identified by other workers (Iribarren et al., 2007). The sequence containing the anticline is overlain by a chaotic facies (the Tortonian Olistostrome) and by horizontal valley fill. The surface of the chaotic facies is deformed, eroded and then sealed by the valley fill. The wedge of the chaotic facies follows the shape of the underlying anticline, and so was either folded with the underlying strata, placing the age of the folding as Tortonian or later, or pushed as a wedge across the anticline. The former seems more likely. The chaotic facies does not pond in the synclinal trough, and so was not deposited in this location after the fold was formed. The NE portion of the chaotic facies is more strongly deformed and uplifted along a NE dipping thrust fault, marking the edge of the active accretionary wedge. This profile thus reveals a sequence of several events; 1) an earlier episode of SW vergent thrusting onto the toe of the adjacent Moroccan margin (presumably until the mid-Miocene), 2) deposition of a NE-ward thickening chaotic sedimentary unit (the Tortonian Olistostrome), 3) deformation of the chaotic facies and thickening, 4) deposition of well stratified horizontal valley fill, sealing the early Miocene wedge and the chaotic facies unit in the Rharb Valley, 5) tectonic reactivation of the chaotic facies along a SW vergent ramp thrust, causing uplift and deformation of the chaotic facies unit. This ramp thrust marks the limit of the active accretionary wedge and its expression at the seafloor coincides with the E-W oriented lineament at the northern limit of the Rharb Valley. This profile clearly shows that the lineament is tectonic in origin and not purely an erosional feature.

Structural Maps (basement, sediment, Moho and crustal maps)

All available seismic profiles (multi-channel reflection, as well as wide angle refraction) were used to construct 3-D grids of the crustal structure in the Gulf of Cadiz area (Fig. 5). The principle 
horizons picked were, the sediment-basement interface and the Moho, with values in two-way way travel time (TWT) sampled every $10 \mathrm{~km}$ along the seismic reflection profiles. The TWT to the top basement reflection was converted to depth using a mean sedimentary velocity of $3 \mathrm{~km} /$ and basement thickness was likewise converted from TWT to depth using a mean velocity of $6 \mathrm{~km} / \mathrm{s}$. Depth sections were available for some seismic profiles, with ocean-bottom seismometer (OBS) data; lines SIS-4 (Contrucci et al., 2004), SIS-16 (Gutscher et al., 2002) and/or where pre-stack depth migration was performed; SIS-22 (Thiebot and Gutscher, 2006) and offered an independent calibration of depth to basement and depth to Moho. On land, depth to basement was taken from published geological maps, which included borehole data in the Guadalquivir and Rharb Basins. All the x,y,z depth to basement points were converted into a depth-to basement grid using the GMT gridding algorithm surface (Wessel and Smith, 1991). In similar fashion all the $\mathrm{x}, \mathrm{y}, \mathrm{z}$ depth to Moho points obtained from the seismic profiles, were taken together with a few values from published Moho maps of NW Africa or the SW Iberia region, and gridded to obtain a 3-D surface to the Moho. Together with the depth to sea-floor grid (obtained from multi-beam bathymetry), three 3-D surfaces were available across the study area. The depth to basement map is shown in Fig. 5A. By taking the difference between the bathymetry and depth to basement grids, it was possible to obtain a sediment thickness map (Fig. 5B). The depth to Moho map is also shown (Fig. 5C), and likewise, by taking the difference between the depth to basement and the depth to Moho maps, it was possible to construct a map of total crustal thickness map (Fig. 5D).

The depth to basement map (Fig. 5A) shows a roughly E-W oriented trough, in the Gulf of Cadiz. On the SW Iberian margin and the NW Moroccan margin, depth to basement is typically about 4-5 $\mathrm{km}$ and decreases to $0.5-2 \mathrm{~km}$ near the coast. Below the adjacent abyssal plains, the depth to basement ranges from about $8-10 \mathrm{~km}$. Within the E-W trough, there is a gradual deepening towards the east, reaching maximum values of $13-14 \mathrm{~km}$. The region of greatest basement depth terminates to the east in a crescent shaped trough, sub-parallel to the Betic-Rif mountain belt. This trough represents the flexural foreland basin caused by the construction of the orogen. It is noteworthy however, that the depth to basement only reaches values of 2-3 km onland (Guadalquivir basin in SW Spain and Rharb Basin in NW Morocco which both overly continental crust), whereas the depth to basement in the Gulf of Cadiz (likely floored by oceanic crust) reaches $12-14 \mathrm{~km}$.

The total sediment thickness map shows similarities to the basement map; a thick, generally E$\mathrm{W}$ oriented sedimentary basin, terminating in a crescent shaped basin in the foreland of the Betic and Rif mountain belts (Fig. 5B). The main difference however, is that while the crescent shaped foreland basin never exceeds values of 3-4 $\mathrm{km}$ on land, the basin centered within the Gulf of Cadiz is more circular and the maximum thickness reaches values of 12-13 km. Again this maximum thickness is located on the central to eastern side of the Gulf of Cadiz. It is possible that sediment thicknesses may 
increase further east, however, no seismic data are available here (between $7^{\circ} \mathrm{W}$ and $6^{\circ} \mathrm{W}$ ). The trends observed here are similar to those described in a recent study of sedimentary thicknesses (Iribarren et al., 2007) where a maximum of $12 \mathrm{~km}$ was reported in the central Gulf.

The regional Moho map reveals four distinct domains, the Iberian and Moroccan continental domains (with a Moho depth of 28-38 km), an Atlantic domain (depths of 12-16 km) and the Alboran domain (with depths of 8-16 km in the East Alboran Sea and 18-20 km in the West Alboran Sea) (Fig. 5C). Moho depth is greatest beneath the Betic Mountains $(34-38 \mathrm{~km})$, where a thick crustal root compensates the highest mountains of the Sierra Nevada (3700 m). A more modest, crescent shaped crustal root appears to underlie the western Betics, the straits of Gibraltar and the SW edge of the Rif mountains (with Moho depths of about $32 \mathrm{~km}$ ), although these regions are not well constrained by wide-angle seismic data. These results are in good agreement with the Moho depth values reported in a recent regional lithospheric study (Fullea et al., 2007).

The crustal thickness map (Fig. 5D) is similar to the Moho map, but the Gulf of Cadiz region appears much more clearly as an E-W corridor of thin crust, with values of 6-10 km. The NW corner of the African continent appears clearly as an angular promontory, with a $\mathrm{N} 30^{\circ} \mathrm{E}$ oriented Atlantic margin to the west, and a roughly $\mathrm{N} 80^{\circ} \mathrm{E}$ oriented "Cadiz margin" to the north. The Alboran region also changes in appearance, with a greater similarity between the western and eastern Alboran domains (crustal thicknesses of 6-10 km separated by a $16 \mathrm{~km}$ thick, NE-SW oriented ridge, passing through Alboran Island.

Interpretation and regional lithospheric structure

As the 3-D geometry of the lithosphere in the Southern Iberia region is rather complex, the results of the crustal maps above will now be discussed within the regional geodynamic framework. A narrow east-dipping slab of dense lithosphere has been imaged in tomographic cross-sections (Gutscher et al., 2002; Spakman and Wortel, 2004) The deep geometry in horizontal however, indicates an asymmetric curved shaped body at depth, elongated parallel to the Betics sections (Wortel and Spakman, 2000; Spakmand and Wortel, 2004) (Figure 6). This high p-wave velocity body at depth, which represents a curved slab of dense lithosphere is the locus of the majority of the intermediate-depth seismicity beneath the West Alboran suggesting it is a slab of oceanic lithosphere, This is confirmed by the dispersion of teleseismic waves passing through this body (Bokelmann and Maufroy, 2007). The presence of a narrow corridor of oceanic lithosphere beneath the western and central Gulf of Cadiz is suggested by the presence of generally E-W oriented magnetic anomalies here (Verhoef et al., 1991) and by the very low crustal thickness observed in the crustal thickness map. Additional seismic studies of the crustal types here would be necessary to test this interpretation, which if confirmed would further support the subduction model. 
It is also instructive to note the numerous sub-parallel arcuate features in the Gibraltar region at depth and at the surface. These include: the high p-wave velocity body (at $200 \mathrm{~km}$ depth beneath the Alboran Sea); the distribution of intermediate earthquakes (60-120 km depth); the sedimentary trough in the West Alboran Sea (as expressed by the negative gravity anomaly and representing the low density sedimentary fill in the arcuate back-arc basin); the surface relief of the Betic and Rif mountain chain (related to the fold and thrust belt which constructed the orogen). West of Gibraltar additional arc shaped features include the gravity minimum in the the Gulf of Cadiz (related to the great sedimentary thickness here and which also has an E-W axis of symmetry) and finally much further west the roughly horseshoe shaped deformation front of the accretionary wedge. It seems inescapable that 6 independent sub-parallel arcuate shaped structures at varying depths and expressed in completely independent data sets must be genetically linked. The only single process, which can explain all these observations, is east-dipping subduction of a narrow slab of oceanic lithosphere (but which is curved at depth) as already suggested by earlier authors (Lonergan and White, 1997).

This lithospheric structure is expressed schematically by two cross-sections (Fig. 7). The longer E-W section crossing Gibraltar passes along the axis of symmetry of the curved subduction system. A 2-D density model of this section (constructed on the basis of seismic refraction p-wave velocities) can successfully predict the observed free-air gravity anomaly along this profile (Thiebot and Gutscher, 2006). The main features are; the deep sedimentary trough in the West Alboran Sea, the thick sedimentary wedge in the Gulf of Cadiz and the east-dipping basement beneath this accretionary wedge. The detailed crustal structure beneath the Rif-Betic mountain belt (near the Straits of Gibraltar) is poorly constrained and somewhat speculative. The N-S cross-section passes along an existing deep seismic sounding profile (Sismar-13) and suggests a corridor of thin crust underlying the accretionary wedge, which may be oceanic in nature. However, more detailed analysis of OBS data will be necessary before this can be conclusively determined.

Summing up, these structural data from the Gulf of Cadiz clearly reveal the presence of an eastward thickening wedge of sediments, situated in an E-W oriented trough, underlain by a thin (6-10 $\mathrm{km}$ ) crust with a gentle eastward dip. This geometry in confirmed by other regional studies and the current consensus is that this thick accumulation of sediments is an accretionary wedge formed by the westward motion of the Gibraltar arc until at least the Miocene (Iribarren et al., 2007). The questions, which remain unresolved, are: is deformation continuing today in this tectonic wedge? And if so is it due to continuing subduction rollback (inducing E-W compression) or could it be caused by the overall NW-SE convergence of Africa and Eurasia? In order to address these questions analog modeling of accretionary wedge growth and subsequent collision with a rigid indenter was performed. 
Analog modeling of accretion and an oblique indenter

An accretionary wedge sliding along a basal detachment (decollement) can be considered to be a critical Coulomb wedge, with material added to the front of the wedge as a series of imbricate thrust slices (Davis et al., 1983). The wedge also deforms internally (along out-of-sequence thrusts and back-thrusts) to maintain a surface profile, which is a function of the basal friction and the internal friction of the material. The sum of the basal slope and surface slope is known as the wedge taper and for regular accretion at the front, a constant wedge taper is maintained. This notion is called critical wedge theory and predicts self-similar behavior, independent of scale (Davis et al., 1983). Therefore, the mechanical behavior of thrust wedges can be modeled (at a smaller scale) using granular materials and successfully reproduces a variety of accretionary processes (frontal accretion, underthrusting and underplating) observed in accretionary wedges worldwide (Lallemand et al., 1994; Gutscher et al., 1998a,b). The impact of subducting asperities (seamounts or linear ridges) can also be modeled using the same approach (Dominguez et al., 1998).

This approach was applied to study the deformation of the Cadiz accretionary wedge and the impact of an oblique ridge on the deformation front. However, since the geometry of the Gulf of Cadiz and Coral Patch Ridge are highly 3-D, the experimental apparatus selected was a 3-D table (Fig. 8), rather than the more commonly used glass-sided 2-D box. A $15 \mathrm{~mm}$ thick layer of granular materials were deposited on a sheet of mylar film. These materials included $4 \mathrm{~mm}$ of glass beads at the base (to obtain the lowest possible basal friction), $10 \mathrm{~mm}$ of sand and $1 \mathrm{~mm}$ of a fine colored cohesive powder to better preserve the fine structure of deformation at the surface. The mylar film and overlying granular layer was pulled beneath a rigid, curved, semi-circular backstop. The shape of the rigid experimental backstop (Fig. 8, Fig. 9 - 0cm) was chosen to represent the overall curvature of the Betic and Rif mountain belts, which form the orogenic core or "backstop" of the subduction system (Fig. 1, Fig. 6). Pulling the film beneath the backstop is kinematically equivalent to pushing the backstop over the film, which represents the westward motion of the Rif-Betic block which led to the construction of the accretionary wedge (Lonergan and White, 1997; Gutscher et al., 2002; Iribarren et al., 2007).

During the initial phase of the experiment (Fig. 9 12-25 cm) frontal accretion occurs with imbrication of a series of thrust slices at a fairly regular spacing. These develop in a curved manner, in response to the backstop shape and a horseshoe-shaped deformation front is rapidly established (Fig. 6 $37-50 \mathrm{~cm}$ ). Next, the rigid oblique ridge approaches the horseshoe-shaped accretionary wedge (Fig. 6 - $63 \mathrm{~cm}$ ). As the oblique ridge begins to collide with the wedge, the propagation of frontal thrusts is blocked, and the deformation front steepens here, while it is free to continue advancing on the left (Fig. $9-76 \mathrm{~cm}$ ). In the final stage the deformation front has become asymmetric, with a marked 
embayment at the point of impact, and a steeper slope here where the indenter has caused underthrusting and some local sliding (frontal erosion) (Fig. 9 - $89 \mathrm{~cm}$ ).

There are some significant differences in the overall geometry of the modeled thrust wedge with respect to the natural example. The submarine accretionary wedge is more elongate (roughly 200 $\mathrm{km} \mathrm{E-W}$ and $150 \mathrm{~km} \mathrm{~N}-\mathrm{S}$ ) and has a shallower surface slope and wedge taper ( $1^{\circ}$ surface slope, with a $2^{\circ}$ mean basal dip and thus $3^{\circ}$ wedge taper) than the model wedge $(\mathrm{N}-\mathrm{S}$ roughly $100 \mathrm{~cm}, \mathrm{E}-\mathrm{W}$ roughly $50 \mathrm{~cm}$, surface slope $6^{\circ}$, basal dip $=0^{\circ}$ and thus $6^{\circ}$ wedge taper). This appears to be a limitation of the dry granular materials used which are stronger (have a higher coefficient of internal friction) than underconsolidated and often overpressured marine sediments. In particular fluid overpressures likely present within the decollement layer, are not reproduced adequately and the ensuing basal friction is thus too high in the model wedge. The accretionary wedge may also contain evaporates which can exhibit some of the weakest rheologies known (Gutscher et al., 2008). The higher basal friction in the model wedge results in a higher taper and shorter length (Davis et al., 1983; Lallemand et al., 1994, Gutscher et al., 1998b). The submarine wedge is much thinner and much longer.

Despite these limitations, the final stage of the experiment with the oversteepened deformation front, and the curved and deflected anticlinal thrust ridges on the accretionary wedge (even locally overriding the ridge itself) (Fig. 10A) is highly reminiscent of the 3-D geometry of the seafloor at the point of impact between Coral Patch Ridge and the deformation front (Fig. 10B). In the natural example the deformation front has clearly advanced further to the north (to the left) and has a gentler surface slope here as well. The asymmetry of the deformation front, with the embayment south of the indenter clearly indicates the relative sense of motion of the backstop with respect to the indenter (equivalent to SW to WSW for the Gulf of Cadiz).

If the primary direction of tectonic shortening pushing the accretionary wedge into the indenter were towards the NW (Africa - Iberia motion), then the embayment would appear on the northern side of the Coral Patch Ridge. The analog model thus unequivocally demonstrates a predominantly WSW compressional motion of the Rif-Betic backstop towards the seafloor in the Horseshoe and Seine abyssal plain region. This tectonic motion (of the Rif - Betic block) is also borne out by GPS data from the region (Fernandes et al., 2007; Stich et al., 2007; Tahayt et al., 2008). As the seafloor morphology (imaged by multi-beam bathymetry) and shallow sediment deformation imaged by highresolution seismic profiles at the intersection of the indenter and the accretionary wedge are all very recent (Gutscher et al., 2008), this demonstrates that the subduction rollback mechanism continues to drive tectonic deformation today. Understanding the plate tectonic forces active today in the region is of primary importance for a proper assessment of the modern day seismic hazard. The first and most important step in this effort is trying to identify the source region of the strongest earthquake in European history the Great Lisbon earthquake of 1755. 
Implication for the 1755 earthquake

Numerous candidate sources have been proposed for the 1755 earthquake; Gorringe Bank, Marquis de Pombal and the Horseshoe fault (Fig. 1). Following the M7.9 St. Vincent earthquake in 1969, which occurred on the Horseshoe Fault in the Horseshoe abyssal plain, some authors proposed this to be the source of the 1755 earthquake as well (Fukao, 1973). The fault plane solution indicates conjugate $\mathrm{N} 60^{\circ}$ striking, $45^{\circ}$ dipping fault planes with a reverse sense of motion. Other authors proposed the nearby Gorringe Bank, an uplifted flake of oceanic crust (rising to a water depth of 25 m), to be the source (Johnston, 1996). Seismic profiles reveal steep scarps and deformed sediments suggestive of recent thrust deformation here (Sartori et al., 1994; Hayward et al., 1999). The potential dimensions of a lithospheric scale thrust fault for Gorringe Bank are about $200 \mathrm{~km}$ x $80 \mathrm{~km}$ (for a 50 $\mathrm{km}$ thick elastic lithosphere, and $40^{\circ}$ fault dip). Using a very high rigidity value of $6.5 \times 10^{10} \mathrm{~Pa}$ (for a fault entirely in oceanic lithosphere), a magnitude of 8.7 was calculated for a uniform slip of $12 \mathrm{~m}$ (Johnston, 1996). For a more typical rigidity value of about $3 \times 10^{10} \mathrm{~Pa}$, a uniform slip of $24 \mathrm{~m}$ would be required to produce an M8.7 event.

More recently, authors have focussed on the Marquis de Pombal, a basement high off the SW corner of Portugal (Zitellini et al., 2001; Gracia et al., 2003a). Tsunami modeling suggests a source located at the Marquis de Pombal structure can provide a reasonable fit for arrival time for most stations, though discrepancies exist for the Gulf of Cadiz and NW Morroccan coast (Baptista et al., 1998). The primary objection to the Marquis de Pombal source, however, is that the dimensions of this structure (about $100 \mathrm{~km} \times 70 \mathrm{~km}$ ) are too modest to produce an earthquake of $\mathrm{M}>8.5$. A calculation using a uniform slip of $15 \mathrm{~m}$, yields only $\mathrm{M}=8.3$ (Zitellini et al., 2001). An event of this magnitude would not be felt in Hamburg or the Cape Verde Islands. Indeed, an empirical relation has been established between earthquake magnitude and the rupture area of the fault on the basis of earthquakes $\mathrm{M} \leq 8$ (Fig. 11) (Wells and Coppersmith, 1994). The relation also holds true when great subduction earthquakes of the past 100 years are added. Thus, according to this relation, the source region of an M8.7 earthquake should be over 30,000 km2 in area (roughly $150 \mathrm{~km} \mathrm{x} 200 \mathrm{~km}$ ) (Fig. 11). Of the known tectonic structures off SW Iberia, only the subduction fault plane (and to a lesser extent Gorringe Bank) has sufficiently large dimensions (Fig. 11).

Finally, some authors have proposed combining a series of faults in a chain, with rupture along one segment triggering rupture along the following segment, and thus attempted to explain the large seismic moment (Gracia et al., 2003; Baptista et al., 2003; Stich et al., 2007). However, even after adding two such segments together (e.g. - the Marquis de Pombal and Horseshoe faults) the surface area is still far too small to generate the appropriate seismic moment (Fig. 11). Three such faults are 
also insufficient. And a scenario where four (or more) small faults rupture in rapid succession becomes increasingly unlikely and untenable as a hypothesis.

\section{Conclusions}

Morpho-bathymetric data from the Gulf of Cadiz image a rugous sea-floor slope with curvilinear ridges and troughs comprising an eastward thickening wedge of tectonically deformed sediments. Deep crustal structural maps are presented which demonstrate that sediment thicknesses in the central Gulf of Cadiz reach a maximum of $12-13 \mathrm{~km}$. The basement beneath the western and central Gulf is generally between 7 and $10 \mathrm{~km}$ thick and forms a roughly E-W oriented trough between the thicker $(20-30 \mathrm{~km})$ continental crust of SW Iberia and NW Morocco. The thick tectonically deformed sedimentary wedge is an accretionary wedge formed by the W to SW migration of the Rif-Betic block. The frontal (western) and lateral (south-eastern) boundaries of the accretionary wedge show signs of recent deformation. Ongoing hydrological activity of the accretionary wedge is indicated by the presence of abundant mud volcanoes (Pinheiro et al., 2003; 2006) as well as the geochemistry of fluids emanating from these mud volcanoes, which indicate an origin due to clay mineral dehydration processes, typical of accretionary wedges (Hensen et al., 2007). Eastward diminishing heatflow as observed on the accretionary wedge also requires active underthrusting (subduction) at rates $\geq 5 \mathrm{~mm} / \mathrm{yr}$ (Grevemeyer et al., 2008). All of these data are consistent with ongoing subduction.

The formation and evolution of the accretionary wedge is investigated by analog modeling. The development of a curved, horseshoe-shaped deformation front is reproduced by accretion against a curved rigid backstop (representing the orogenic core of the Rif and Betic Mountain belts). The collision of an oblique trending linear ridge with the accretionary wedge is modeled as well. The impact is an asymmetric deformation front with an embayment (to the south) marked by a steeper surface slope. These morphological features successfully reproduce the seafloor morphology imaged by the bathymetric data and provide kinematic constraints on the relative shortening between the RifBetic block and the oceanic abyssal plains in the Atlantic domain to the west. These demonstrate a WSW directed relative convergence direction, driven by subduction roll-back. The tectonic activity of the subduction system has a strong impact on the seismic hazard assessment for the region. Indeed, the shallow east-dipping subduction fault plane has the appropriate dimensions $(180 \mathrm{~km} \mathrm{~N}-\mathrm{S} \times 210$ $\mathrm{km}$ E-W) to generate an earthquake of magnitude 8.6 for $10 \mathrm{~m}$ of uniform co-seismic slip. The subduction fault plane is the only single tectonic structure in the region with sufficiently large dimensions to generate such a great earthquake.

\section{Acknowledgments}


Thanks to the Captain and the crew of the Portuguese R/V Dom Carlos and to the Instituto Hidrografico for acquisition and processing of the Delila bathymetric data. We also thank D. Blamart (LSCE-CEA/CNRS-UVSQ) chief scientist, H. Leau (IPEV) Chief of the operations and the Captain and crew of the R/V Marion Dufresne for acquisition of bathymetric data during the Microsystems cruise. Additional bathymetric data from the 2006 R/V Charles Darwin Hermes cruise were kindly provided by D. Masson, NOC Southampton. We gratefully acknowledge financial support through the French GDR Marges project and the ESF Euromargins program as well as the European FP6 Project "Nearest". We thank the reviewers for constructive comments. Figures 1, 2, 5, 6, 7 and 10b were drafted using GMT software (Wessel and Smith, 1991). This paper is IUEM contribution number XXXX.

\section{References}

Babonneau, N., Gutscher, M.-A., Gonthier, E., Mulder, Th., 2006. Turbidite sequences in the deep basins offshore SW Iberia as possible paleoseismological markers. Proc. EGU Meeting, Vienna, Apr. 2006, Geophysical Research Abstracts, v. 8, CD-ROM.

Baptista, M.A., Miranda P.M.A., Miranda, J.M., and Mendes Victor, L., 1998. Constraints on the source of the 1755 Lisbon tsunami inferred from numerical modelling of historical data on the source of the 1755 Lisbon tsunami. J. Geodynamics, 25, 159-174.

Baptista, M.A., Miranda P.M.A., Chierici, F., and Zitellini, N., 2003. New study of the 1755 earthquake source based on multi-channel seismic survey data and tsunami modeling. Natural Hazards and Earth Science Systems, 3, 333-340.

Bokelmann, G., Maufroy, E., 2007, Mantle structure under Gibraltar constrained by seismic waveform complexity, Geophys. Res. Let., 34, L22305, doi:10.1029/2007GL030964

Calvert, A., Sandvol, E., Seber, D., Barazangi, M., Roecker, S., Mourabit, T., Vidal, F., Alguacil, G., and Jabour, N., 2000, Geodynamic evolution of the lithosphere and upper mantle beneath the Alboran region of the western Mediterranean: Constraints from travel time tomography: Journal of Geophysical Research, 105, 10871-10898.

Contrucci, I., Klingelhoefer, F., Perrot, J., Bartolome, R., Gutscher, M.-A., Sahabi, M., Malod, J., and Rehault, J.-P., 2004. The crustal structure of the NW-Moroccan continental margin from wideangle and reflection seismic data. Geophysical Journal International, 159, 117-128.

Davis, D., Suppe, J. and Dahlen, F., 1983. Mechanics of fold and thrust belts and accretionary wedges. J. Geophys. Res., 88, 1153-1172.

Dezes, P., and Ziegler, P.A., 2001. European Map of the Mohorovicic discontinuity. 2nd EUCORURGENT Workshop (Upper Rhine Graben Evolution and Neotectonics), Mt. St. Odile, France. (available for download at web site - http://comp1.geol.unibas.ch/index.php ) 
Dominguez, S., Lallemand, S.E., Malavieille, J., and von Huene, R., 1998. Upper plate deformation associated with seamount subduction. Tectonophysics, 293, 207-224.

Duggen, S., Hoernle, K., van den Bogaard, P., Harris, C., 2004. Magmatic evolution of the Alboran Region: The role of subduction in forming the western Mediterranean and causing the Messinian Salinity Crisis. Earth Planet. Sci. Lett., 218, 91-108.

Fadil, A., Vernant, P., McClusky, S., Reilinger, R., Gomez, F., Ben Sari, D., Mourabit, T., Feigl, K., and Barazangi, M., 2006. Active tectonics of the western Mediterranean: evidence for roll-back of a delaminated subcontinental lithospheric slab beneath the Rif Mountains Morocco. Geology, 34, 529-532.

Fernandes, R.M.S., Miranda, J.M., Meijninger, R.M.L., Bos, M.S., Noomen, R., Bastos, L., Ambrosius, B.A.C., and Riva, R.E.M., 2007. Surface velocity field of the Ibero-Maghrebian segment of the Eurasia-Nubia plate boundary. Geophysical Journal International, 169, 315-324.

Fukao, Y., 1973. Thrust faulting at a lithospheric plate boundary: The Portugal earthquake of 1969. Earth Planet. Sci. Lett., 18, 205-216.

Fullea, J., Fernandez, M., Zeyen, H., Verges, J., 2007. A rapid method to map the crustal and lithospheric thickness using elevation, geoid anomaly and thermal analysis. Application to the Gibraltar Arc System, Atlas Mountains and adjacent zones. Tectonophysics, 430, 97-117. doi:10.1016/j.tecto.2006.11.003

Gracia, E., Danobeitia, J.J., Verges, J., PARSIFAL Team, 2003a. Mapping active faults offshore Portugal $\left(36^{\circ} \mathrm{N}-38^{\circ} \mathrm{N}\right)$ : Implications for seismic hazard assessment along the southwest Iberian margin. Geology 31, 83-86.

Gracia, E., Danobeitia, J.J., Verges, J., Bartolome, R., 2003b. Crustal architecture and tectonic evolution of the Gulf of Cadiz (SW Iberian margin) at the convergence of the Eurasian and African plates. Tectonics, 22, n.4, 1033, doi:10.1029/2001TC901045.

Grevemeyer, I., Kaul, N., and Kopf, A., 2008. Heat flow anomalies in the Gulf of Cadiz and off Cape San Vicente, Portugal. Marine and Petroleum Geology, doi:10.1016/j.marpetgeo.2008.08.006.

Gutscher, M.-A., Kukowski, N., Malavieille, J. and Lallemand, S., 1998a. Episodic imbricate thrusting and underthrusting: Analog experiments and mechanical analysis applied to the Alaskan accretionary wedge. Journal of Geophysical Research, v. 103, p. 10161-10176.

Gutscher, M.-A., Kukowski, N., Malavieille, J., and Lallemand, S., 1998b. Material transfer in accretionary wedges from analysis of a systematic series of analog experiments. Journal of Structural Geology, v. 20, p. 407-416.

Gutscher, M.-A., Malod, J., Rehault, J.-P., Contrucci, I., Klingelhoefer, F., Mendes-Victor, L., Spakman, W., 2002. Evidence for active subduction beneath Gibraltar. Geology, 30, 1071-1074.

Gutscher, M.-A., 2004. What caused the Great Lisbon Earthquake? Science, v. 305, p. 1247-1248. 
Gutscher, M.-A., Baptista, M.A., Miranda, J.M., 2006. The Gibraltar Arc seismogenic zone (part 2): constraints on a shallow east dipping fault plane source for the 1755 Lisbon earthquake provided by tsunami modeling and seismic intensity. Tectonophysics, Sp. Vol. "Natural laboratories on seismogenic faults”, v. 427, p. 153-166, doi:10.1016/j.tecto.2006.02.025.

Gutscher, M.-A., Dominguez, S., Westbrook, G., Gente, P., Babonneau, N., Mulder, T., Gonthier, E., Bartolome, R., Luis, J, Rosas, F., Terrinha, P., and the Delila and DelSis Scientific Teams. 2008. Tectonic shortening and gravitational spreading in the Gulf of Cadiz accretionary wedge: observations from multi-beam bathymetry and seismic profiling. Journal of Marine and Petroleum Geology, Sp. Vol. on Submarine instabilities. doi:10.1016/j.marpetgeo.2007.11.008

Hatzfeld, D., and Bensari, D., 1977. Grands profils sismiques dans la région de l'arc de Gibraltar. Bull. Soc. Geol. Fr., 7, 749-756.

Hayward, N., Watts, A.B., Westbrook, G.K., and Collier, J.S., 1999. A seismic reflection and GLORIA study of compressional deformation in the Gorringe Bank region, eastern North Atlantic. Geophys. J. Int., 138: 831-850.

Hensen, C., Nuzzo, M., Hornibrook, E.R.C., Pinheiro, L., Bock, B., Magalhaes, V.H. and Brückmann, W., 2007. Sources of mud volcano fluids in the Gulf of Cadiz - indications for hydrothermal input, Geochim. Cosmochim. Acta, v.71, 1232-1248 doi:10.1016/j.gca.2006.11.022

IOC, IHO and BODC, 2003. "Centenary edition of the GEBCO Digital Atlas", published on CDROM on behalf of the Intergovernmental Oceanographic Commission and the International Hydrographic Organization as part of the General Bathymetric Chart of the Oceans; British Oceanographic Data Centre, Liverpool.

Iribarren, L., Verges, J., Camurri, F., Fullea, J., Fernandez, M., 2007. The structure of the AtlanticMediterranean transition zone from the Alboran Sea to the Horseshoe Abyssal Plain (Iberia Africa plate boundary). Marine Geology, 243, 97-119. doi:10.1016/j.margeo.2007.05.011

Jimenez-Munt, I., Fernandez, M., Torne, M., and Bird, P., 2001. The transition from linear to diffuse plate boundary in the Azores-Gibraltar region. Earth and Planet. Sci. Lett., 192, 175-189.

Johnston, A., 1996. Seismic moment assessment of earthquakes in stable continental regions - III. New Madrid, 1811-1812, Charleston 1886 and Lisbon 1755. Geophys. J. Int. 126, 314-344.

Lallemand, S., Schnürle, P. and Malavieille, J., 1994. Coulomb theory applied to accretionary and nonaccretionary wedges: Possible causes for tectonic erosion and/or frontal accretion. Journal of Geophysical Research, 99, 12033-12055.

Lay, T., Kanamori, H., Ammon, C.J., Nettles, M., Ward, S.N., Aster, R.C., Beck, S.L., Bilek, S.L., Brudzinski, M.R., Butler, R., DeShon, H.R., Ekstrom, G., Satake, J., and Sipkin, S., 2005. The Great Sumatra-Andaman earthquake of 26 December 2004. Science, 308, 1127-1133.

Lonergan, L. and White, N., 1997. Origin of the Betic-Rif mountain belt. Tectonics, 16, 504-522. 
Maestro, A., Somoza, L., Medialdea, T., Talbot, C.J. Lowrie, A., Vazquez, J.T. and Diaz-del-Rio, V., 2003. Large-scale slope failure involving Triassic and Middle Miocene salt and shale in the Gulf of Cadiz, Terra Nova, 15, 380-391.

Martinez-Solares, J.M., Lopez A., and Mezcua, J., 1979. Isoseismal map of the 1755 Lisbon earthquake obtained from Spanish data. Tectonophysics, 53, 301-313.

Medialdea, T., Vegas, R., Somoza, L., Vazquez, J.T., Maldonado, A., Diaz-del-Rio, V., Maestro, A., Cordoba, D., and Fernandez-Puga, M.C., 2004. Structure and evolution of the "Olistostrome" complex of the Gibraltar Arc in the Gulf of Cadiz (eastern Central Atlantic): evidence from two long seismic cross-sections. Marine Geology, 209, 173-198.

Mulder, T., Voisset, M., Lecroart, P., Le Drezen, E. Gonthier, E., and the Cadisar Shipboard Party, 2003. The Gulf of Cadiz: an unstable giant contouritic levee. Geo-Marine letters, 23, 7-18.

Mulder, T., Lecroart, P., Hanquiez, V., Marches, E., Gonthier, E., Guedes, J.C., Thiebot, E., Jaaidi, B., Kenyon, N., Voisset, M., Perez, C., Sayago, M., Fuchey, Y., and Bujan, S., 2006. The western part of the Gulf of Cadiz: contour currents and turbidity currents interactions, Geo-Marine Letters, 26, 31-41.

Pinheiro, L.M., Ivanov, M.K., Sautkin, A., Akhmanov, G., Magalhaes, V.H., Volkonskaya, A., Monteiro, J.H., Somoza, L., Gardner, J., Hamouni, N., Cunha, M.R., 2003. Mud volcanism in the Gulf of Cadiz: results from the TTR-10 cruise. Marine Geology 195, 131-151.

Pinheiro, L.M., et al. 2006. MV Seis: Tectonic control, deep crustal structure and fluid escape pathways in the Gulf of Cadiz Mud Volcano Field. EuroMargins Interim Report, ESF Project 01LEC-EMA24F.

Platt, J.P., and Vissers, R.L.M., 1989, Extensional collapse of thickened continental lithosphere: A working hypothesis for the Alboran Sea and Gibraltar arc: Geology, v. 17, p. 540-543.

Sandwell, D.T., Smith, W.H.F., 1997. Marine gravity anomaly from Geosat and ERS 1 satellite altimetry. J. Geophys. Res. 102, 10039-10054.

Sartori, R., Torelli, L., Zitellini, N., Peis, D., Lodolo, E., 1994. Eastern segment of the AzoresGibraltar line (central-eastern Atlantic): An oceanic plate boundary with diffuse compressional deformation. Geology 22, 555-558.

Spakman, W. and Wortel, R., 2004 A tomographic view on Western Mediterranean Geodynamics. in The TRANSMED Atlas. The Mediterranean region from crust to mantle. Geological and Geophysical framework. 2004. Cavazza, W., Roure, F., Spakman, W., Stampfli, G., and Ziegler, P. (Eds.) Episodes, v. 27, p. 31-52.

Stich, D., Mancilla F.d.L., Pondrelli S., Morales, J., 2007. Source analysis of the February 12th 2007, Mw 6.0 Horseshoe earthquake : Implications for the 1755 Lisbon earthquake. Geophys. Res. Lett., v. 34, L12308, doi:10.1029/2007GL030012. 
Stich, D., Serpelloni, E., Mancilla, F.d.L., Morales, J., 2007. Kinematics of the Iberia - Maghreb plate contact from seismic moment tensors and GPS observations. Tectonophysics, v. 426, 295317, doi:10.1016/j.tecto.2006.08.004

Tahayt, A., Mourabit, T., Rigo, A., Feigl, K.L., Fadil, A., McClusky, S., Reilinger, R., Serroukh, M., Ouazzani-Touhami, A., Ben-Sari, D., and Vernant, P., 2008. Mouvements actuels des blocs tectoniques dans l'arc Bético-Rifain à partir des mesures GPS entre 1999 et 2005. Comptes Rendus Geoscience, 340, 400-413.

Terrinha, P., Pinheiro, L.M., Henriet, J.-P., Matias, L., Ivanov, A.K., Monteiro, J.H., Akhmetzhanov, A., Volkonskaya, Cunha, M.R., Shaskin, P., Rovere, M., 2003. Tsunamigenic-seismogenic structures, neotectonics, sedimentary processes and slope instability on the Southwest Portuguese Margin. Marine Geology 195, 1-19.

Terrinha, P., Matias, L., Vicente, J., Duarte, J., Luís, J., Pinheiro, L., Lourenço, N., Diez, S., Rosas, F., Magalhães, V., Valadares, V., Zitellini, N., Roque, C., Mendes Víctor, L., and MATESPRO Team, (in press). Strain partitioning and morpho-tectonics at the Iberia-Africa plate boundary from multibeam and seismic reflection data. Marine Geology, (in press).

Thiebot, E., and Gutscher, M.-A., 2006. The Gibraltar Arc seismogenic zone (part1): constraints on a shallow east dipping fault plane source for the 1755 Lisbon earthquake provided by seismic data, gravity and thermal modeling. Tectonophysics Sp. Vol. "Natural laboratories on seismogenic faults", v. 427, p. 135-152, doi:10.1016/j.tecto.2006.02.024.

Torelli, L., Sartori, R., and Zitellini, N., 1997. The giant chaotic body in the Atlantic off Gibraltar: new results from a deep seismic reflection survey: Marine and Petroleum Geology, 14, 125-138.

Tortella, D., Torne, M, and Perez-Estaun, A., 1997. Geodynamic evolution of the eastern segment of the Azores-Gibraltar Zone: the Gorringe Bank and Gulf of Cadiz region, Marine Geophys. Res. 19, 211-230.

van der Meijde, M., van der Lee, S. and Giardini, D., 2003. Crustal structure beneath broad-band seismic stations in the Mediterranean region. Geophys. J. Int., 152, 729-739.

Verhoef, J., Collette, B.J., Danobeitia, J.J., Roeser, H.A., and Roest, W.R., 1991. Magnetic anomalies off West-Africa, Mar. Geophys. Res., 13, 81-103.

Wells, D., and Coppersmith, K., 1994. New empirical relationships among magnitude, rupture length, rupture width, rupture area and surface displacement. Bull. Seism. Soc. Am. 84: 974-1002.

Wessel, P., and W.H.F. Smith, 1991. Free software helps map and display data, EOS 72, 441.

Wortel, M.J.R. and Spakman, W., 2000, Subduction and slab detachment in the MediterraneanCarpathian region: Science, v. 290, p. 1910-1917.

Working Group for Deep Seismic sounding in Spain 1974-1975, 1978. Crustal seismic profiles in the Alboran Sea - Preliminary results. Pure Appl. Geophys., 116, 167-180. 
Zitellini, N., et al., 2001. Source of 1755 Lisbon earthquake and tsunami investigated. Eos (Transactions, American Geophysical Union) 82, 285-291. 
Figure Captions

Figure 1: General location map, seismicity and primary faults of the S. Iberian / N. Moroccan region (after Gutscher, 2004). Shaded hill relief shown here in background and in Figures 5 and 6 from Gebco 1 min global grid (IOC et al., 2003). Major earthquakes $(M>6)$ are shown with date. Dashed line represents likely position of plate boundary separating Iberia (Eurasia) from Africa (Nubia) and defining a third, pie-shaped block (the Rif-Betic-Alboran domain). The green shaded faults; $G=$ Gorringe Bank (Johnston, 1996), HF = Horseshoe Fault (Gracia et al., 2003a; Stich et al., 2007), Mq= Marques de Pombal (Zitellini, et al., 2001; Gracia et al., 2003a) as well as the subduction fault plane (below the accretionary wedge) (Gutscher, 2004; Gutscher et al., 2006) have been proposed as being the potential source of the 1755 M8.7 Great "Lisbon" earthquake.

Figure 2: Seafloor morphology of the Gulf of Cadiz A: Compilation of multibeam bathymetric data acquired during the following cruises: GAP (Kopf et al., 2003); Cadisar (Mulder et al., 2003); Cadisar2 (Mulder et al., 2006); MatesPro (Terrinha et al., in press); TV-GIB (Gutscher, 2005); Hermes (D. Masson, R/V Charles Darwin, 2006); Delila and DelSis (Gutscher et al., 2008) and Microsystems (D. Blamart, R/V Marion Dufresne, July 2008). In regions without multi-beam coverage colored contour lines are shown every $200 \mathrm{~m}$ from the GEBCO $1 \mathrm{~min}$ grid (IOC et al., 2003). Red lines show the portions of seismic profiles presented in the paper below, with the numbers indicating the figure numbers. B: 3-D perspective view looking $\mathrm{E}$ towards the straits of Gibraltar. Note the WNW-ESE trending basement high (Coral Patch Ridge) indenting the SW portion of the accretionary wedge.

Figure 3: High resolution Chirp seismic profiles acquired by the R/V Suroit (DelSis cruise) in April 2005

A: NE-SW oriented chirp profile (SE at right) crossing the toe of the deformation front (profile is 9 $\mathrm{km}$ long, 1 trace $=3 \mathrm{~m}$ ). Note highly reflective strata at adjacent abyssal plain and folded strata on the accretionary wedge $(\mathrm{VE}=30)$.

B: N-S chirp profile ( $\mathrm{N}$ at left) crossing northern limit of Rharb Valley fault at $6^{\circ} 56^{\prime} \mathrm{W}$ and a mean depth of 500-

$600 \mathrm{~m}$, (profile length $=15 \mathrm{~km})$ note folded and eroded strata $(\mathrm{VE}=30)$.

$\mathrm{C}$ : NNE-SSW chirp profile ( $\mathrm{N}$ at right) on Moroccan shelf (crossing the prolongation of the Rharb Valley fault at $6^{\circ} 39^{\prime} \mathrm{W}$ ) at $115-135 \mathrm{~m}$ water depth, note folded strata and discordance at 120$130 \mathrm{~m}$ depth, likely due to the sea-level lowstand during the Last Glacial Maximum (VE=40) 
Figure 4: DelSis line 29 (24-channel seismic profile) acquired by the R/V Suroit in April 2005. The profile crosses the entire Rharb submarine valley at $2800 \mathrm{~m}$ depth and images an anticline at the base, overlain by a chaotic facies (Tortonian Olistostrome) and by horizontal valley fill. Note the upper surface of the chaotic facies is slightly deformed and then sealed by the valley fill. The NE portion of the chaotic facies is more strongly deformed and uplifted along a SE dipping thrust fault, marking the edge of the active accretionary wedge.

Figure 5: Structural maps of the S. Iberian / N. Moroccan region A: depth to basement map obtained from joint interpretation of all seismic profiles shown (Thiebot and Gutscher, 2006); B: sediment thickness map obtained by combining relief (adding topography and subtracting bathymetry) with the depth to basement map; $\mathrm{C}$ : depth to Moho map obtained by integrating all published seismic reflection, and seismic refraction profiles (Hatzfeld and Bensari, 1977; Working Group, 1978; Banda and Ansorge, 1980; Docherty and Banda, 1995; Seber et al., 2001; Gutscher et al., 2002; Contrucci et al., 2004). Where no seismic data were available (NE Atlantic, Iberia or NW Africa) some values were taken from regional crustal thickness compilations of the Mediterranean region (van der Meijde et al., 2003; Dezes and Ziegler, 2001) D: crustal thickness map obtained by subtracting depth to basement from depth to Moho map.

Figure 6: Relief map of Southern Iberia region (Gebco 1 min grid - IOC et al., 2003), with location of arcuate structures shown in map view (see explanation in Figure). Six independent arc-shaped features can be identified at depths ranging from 60-200 km to the surface, and are aligned along a WSW-ENE axis of symmetry, along the trend of the straits of Gibraltar. Regions likely floored by oceanic crust are shown in yellow. TAP $=$ Tagus Abyssal Plain, HAP $=$ Horseshoe Abyssal Plain, SAP $=$ Seine Abyssal Plain, Gor $=$ Gorringe Bank, $\mathrm{CP}=$ Coral Patch seamount, GR = Guadalquivir Ridge; WAS = West Alboran Sea. (More details are given in the text.)

Figure 7: (Top) Free-air gravity anomaly map of the Gulf of Cadiz - Alboran Sea region (Sandwell and Smith, 1997) with location of Sismar seismic profiles shown (Gutscher et al., 2002; Contrucci et al., 2004). (Abbreviations are the same as in Fig. 6.) Most gravity maxima are associated with basement highs (e.g. - Gorringe Bank, Coral Patch seamount, etc.) or continental margins. (Bottom) Two schematic lithospheric cross-sections, with co-located 2-D free-air gravity anomaly profiles (red dots). Locations indicated on the free-air gravity map above. Gravity minima are typically associated with thick sedimentary accumulations. 
Figure 8: Experimental set-up of analog model using granular materials. The curved backstop consists of a thin, rigid board overlain by a $4 \mathrm{~cm}$ thick layer of sand. Tectonic convergence is simulated by pulling a mylar film beneath the rigid backstop. The layer of granular materials overlying the mylar consists of a $10 \mathrm{~mm}$ thick layer of sand and $1 \mathrm{~mm}$ cohesive colored powder overlying a $4 \mathrm{~mm}$ thick glass bead layer. These granular materials are progressively scraped off and accumulate against the curved backstop.

Figure 9: Photographs at different stages of the analog modeling experiment, with the amount of convergence indicated in $\mathrm{cm}$ in each case. $0 \mathrm{~cm}$ is the initial stage. The rose colored sand on the edges also overlies the mylar film and represents the SW Iberian and NW Moroccan continental margins.

Figure 10: Comparison of experiment and sea-floor morphology. A: Close-up of final stage of experiment (after $89 \mathrm{~cm}$ of shortening) B: Close-up 3-D bathymetric view of Coral-Patch Ridge indenting the deformation front. Note in both cases, the asymmetric shape of the deformation front, with the embayment to the right associated with a steeper frontal slope.

Figure 11: Empirical relation between fault surface area and earthquake magnitude (redrawn after Wells and Coppersmith, 1994). Several large subduction earthquakes have been included like the Sumatra 2004 M9.3 and 2005 M8.7 events (Lay et al., 2005) and the Chile 1960 M9.5 and Alaska 1964 M9.2 earthquakes. The surface areas of various candidate faults for the 1755 Lisbon earthquake have been plotted (see Fig. 1 and caption to Fig. 1 for references). Note that only the subduction fault plane has sufficient dimensions (180 km x $210 \mathrm{~km})$ to generate a $\mathrm{M}>8.5$ earthquake. 


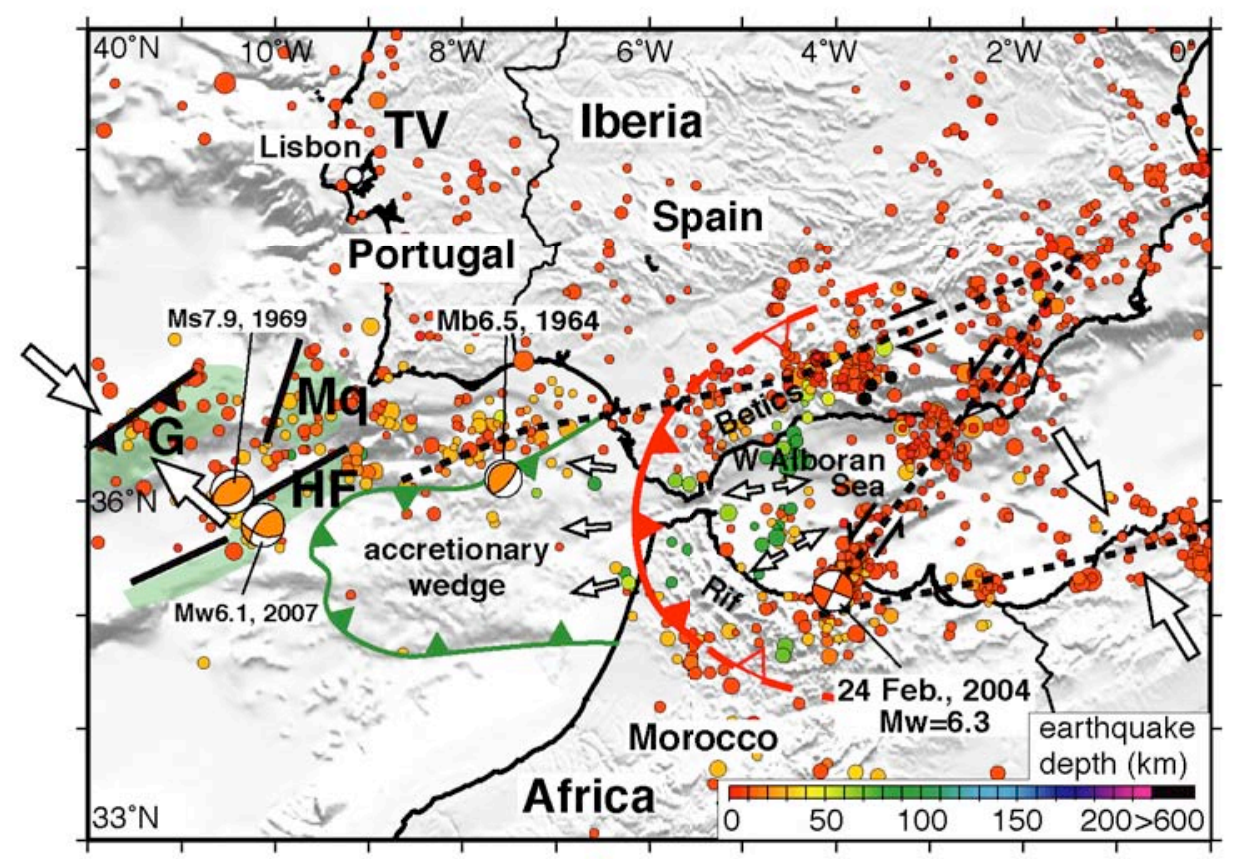



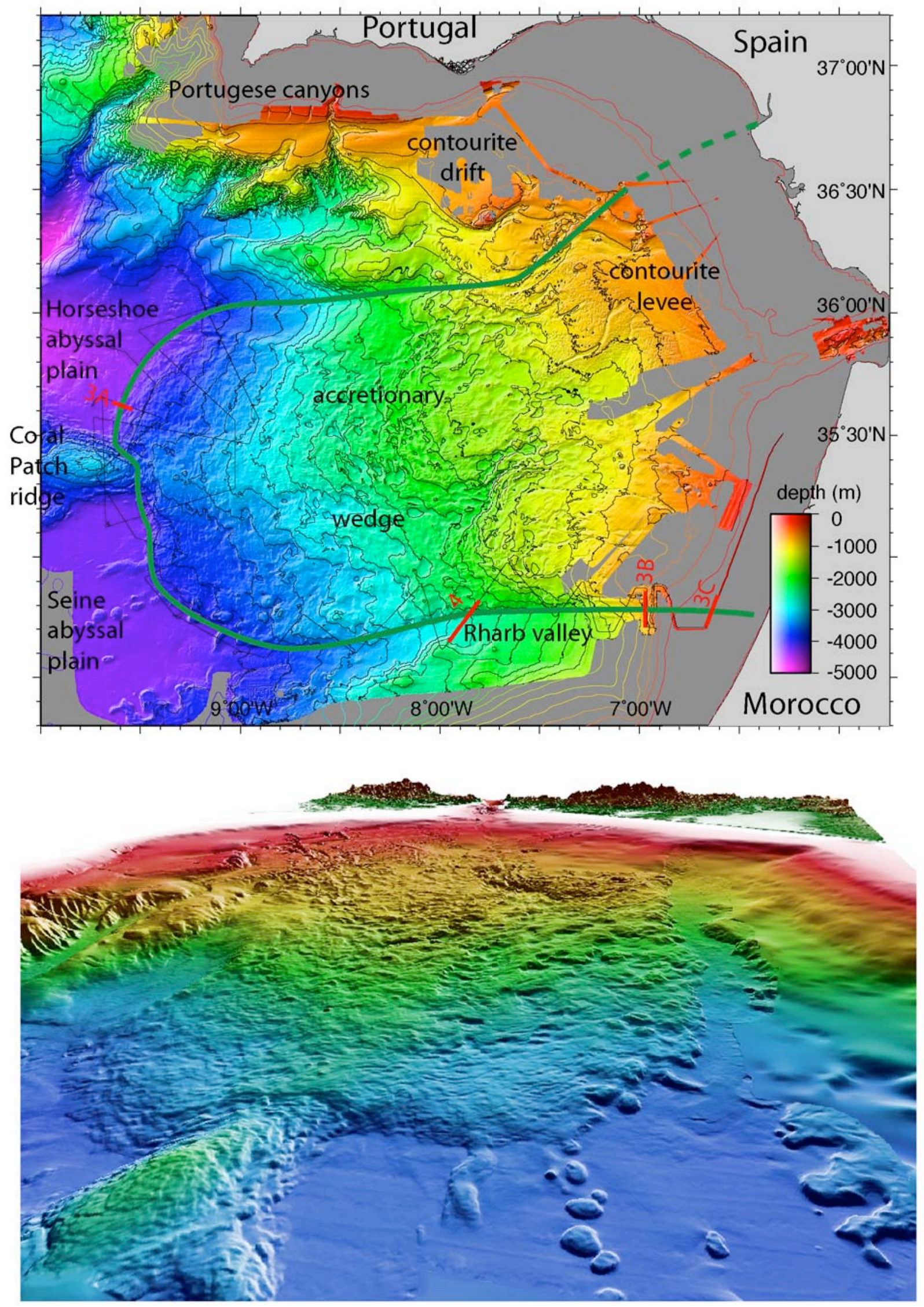

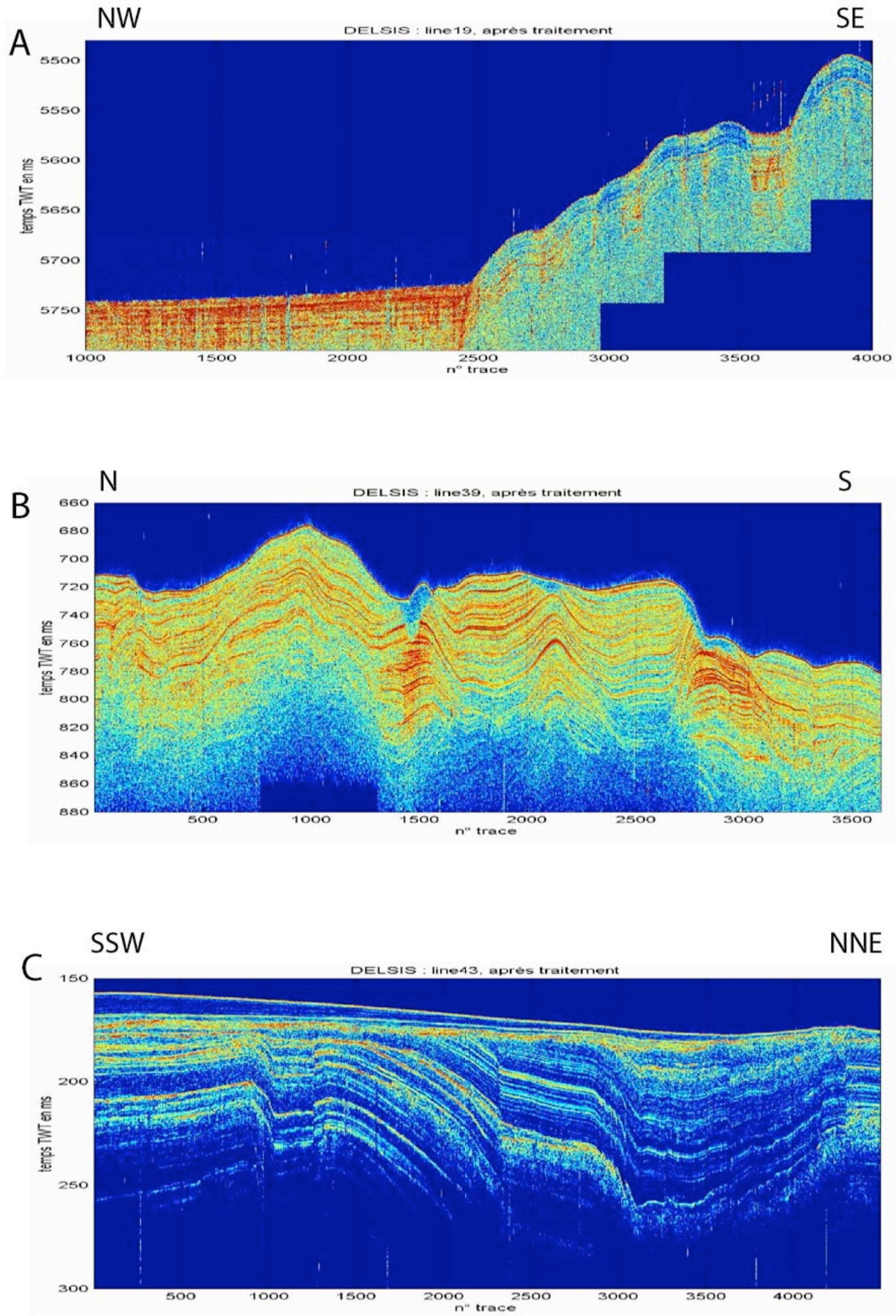
DELSIS - C:ISisrap IStudyDELSISImigrationidata\29 mig seg
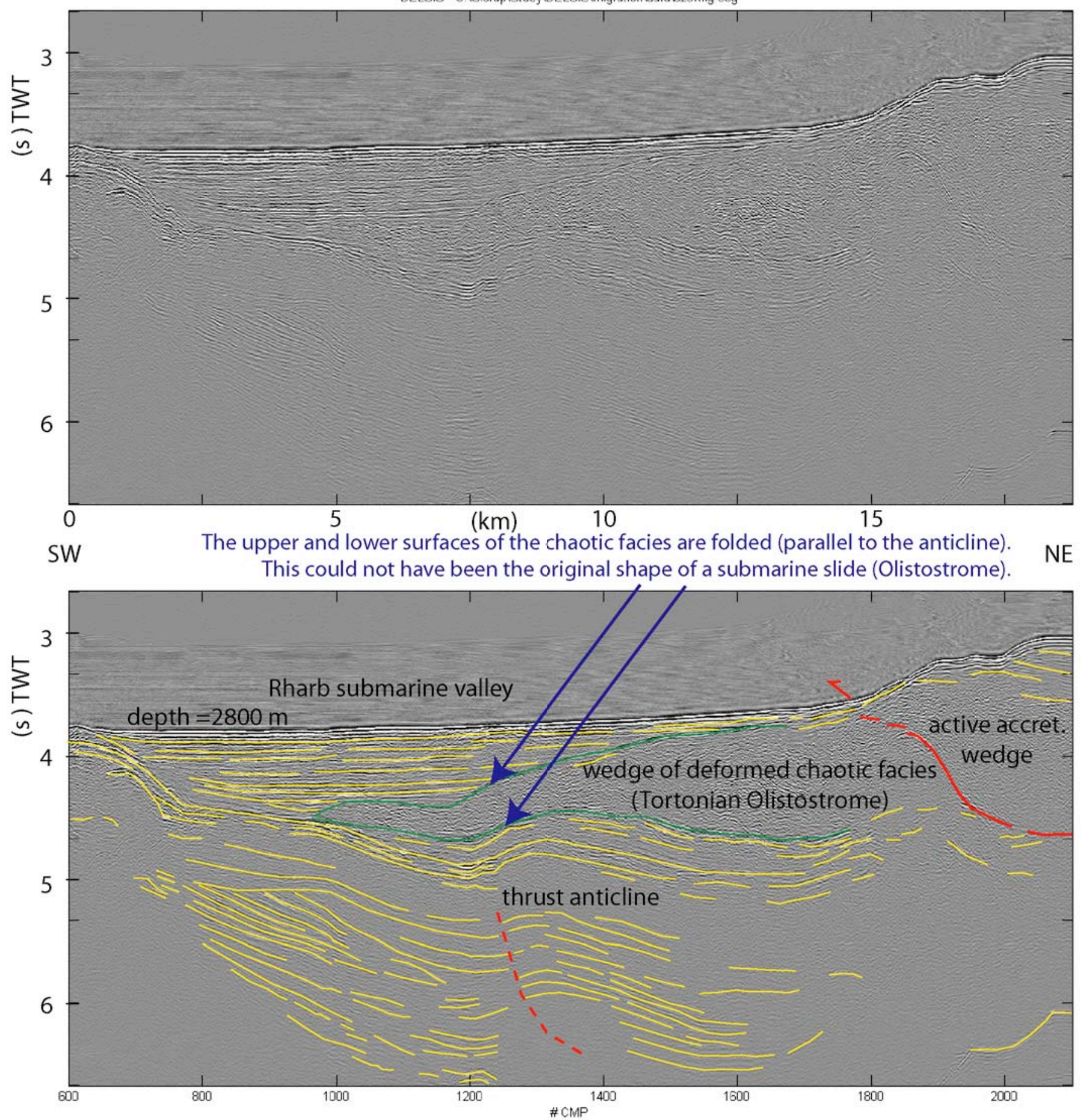

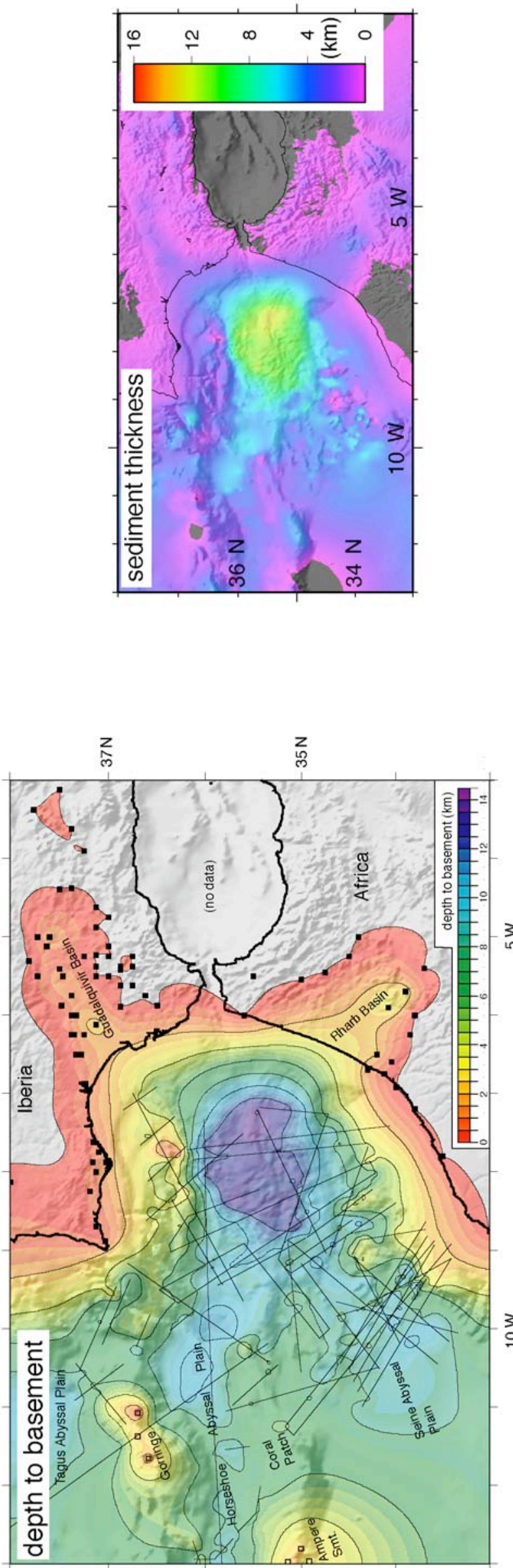
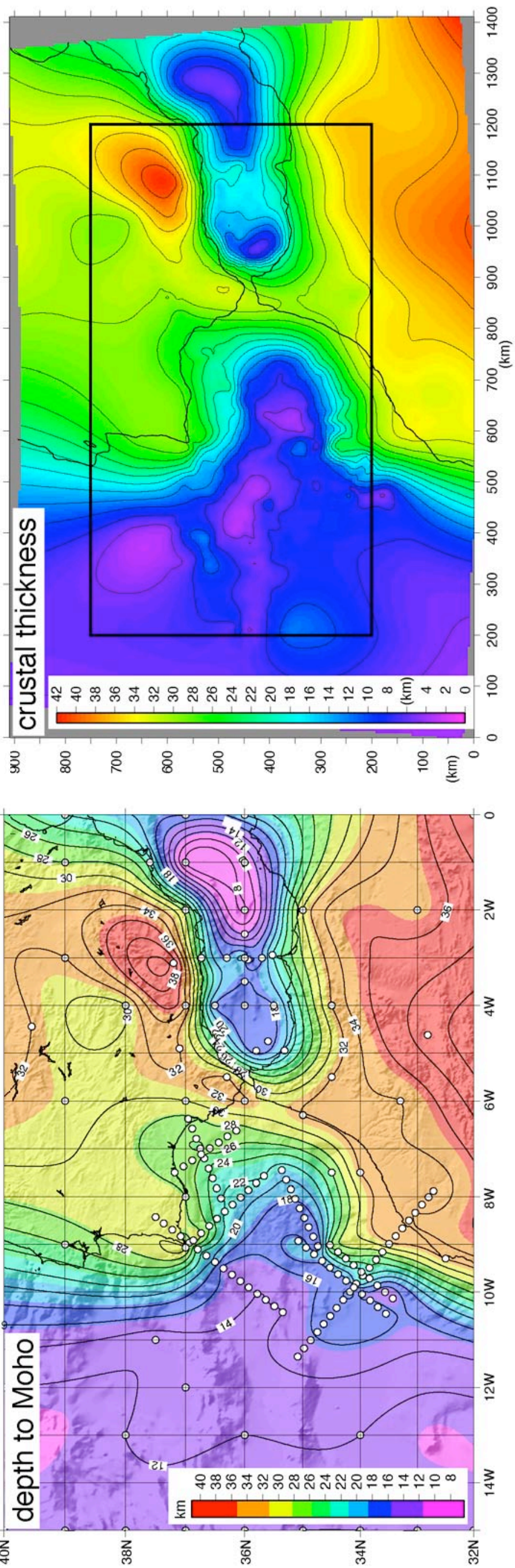


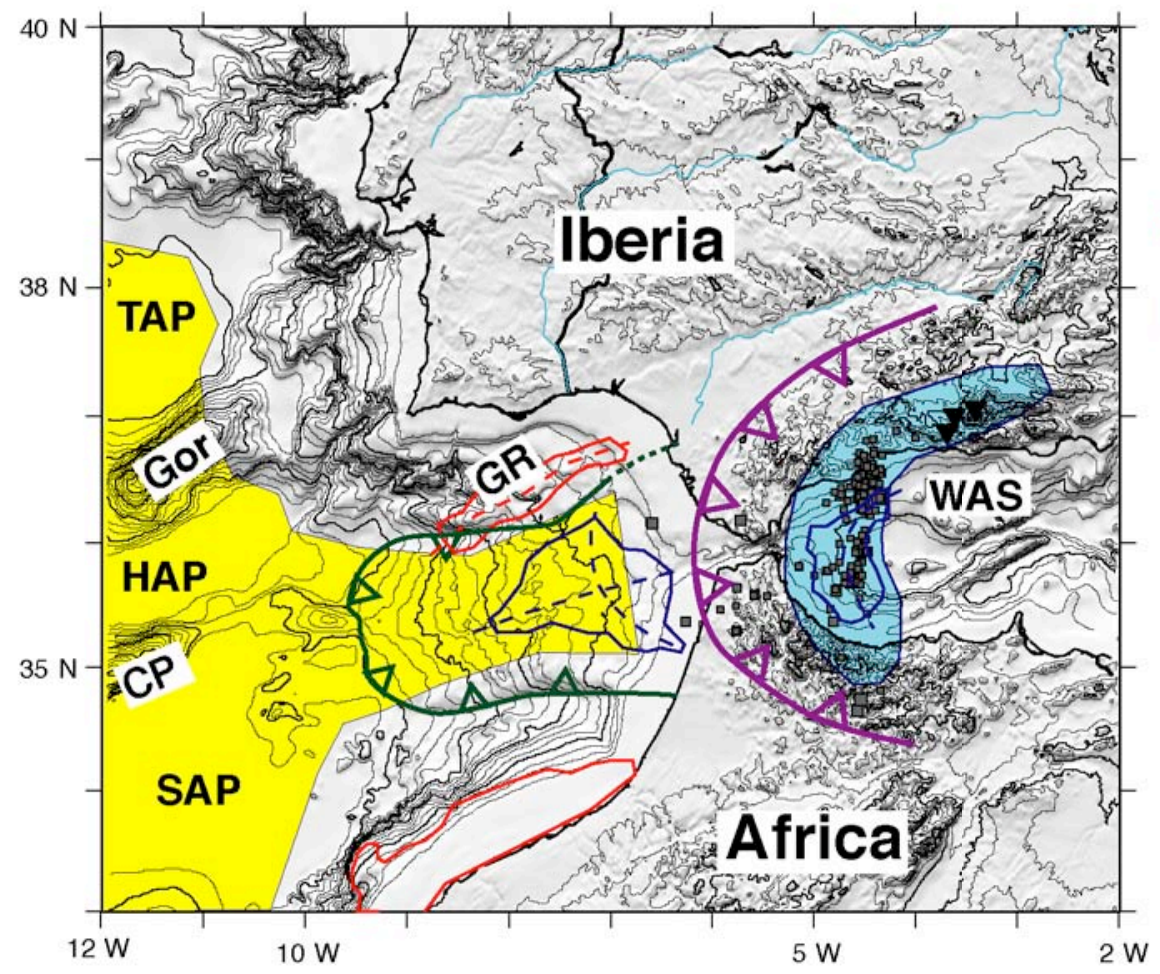

is
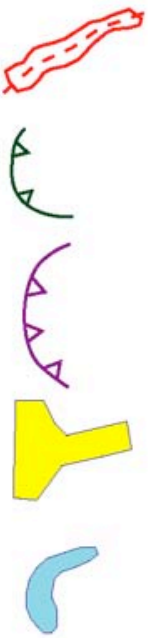

-

$-$

free-air gravity low (<-50 mGal) with axis of anomaly indicated

free-air gravity high (>20 mGal) with axis of anomaly indicated

deformation front of accretionary wedge (active $\mathrm{W}$ vergent thrusting)

limit of Internal Rif and Betic allocthonous units

likely extent of oceanic crust (based on magnetic anomalies and crustal thickness)

high $\mathrm{p}$-wave velocity anomaly in tomography at $200 \mathrm{~km}$ depth (Wortel and Spakman, 2000)

intermediate depth seismicity (60 - $120 \mathrm{~km}$ depth)

deep focus seismicity (600 - $660 \mathrm{~km}$ depth) 

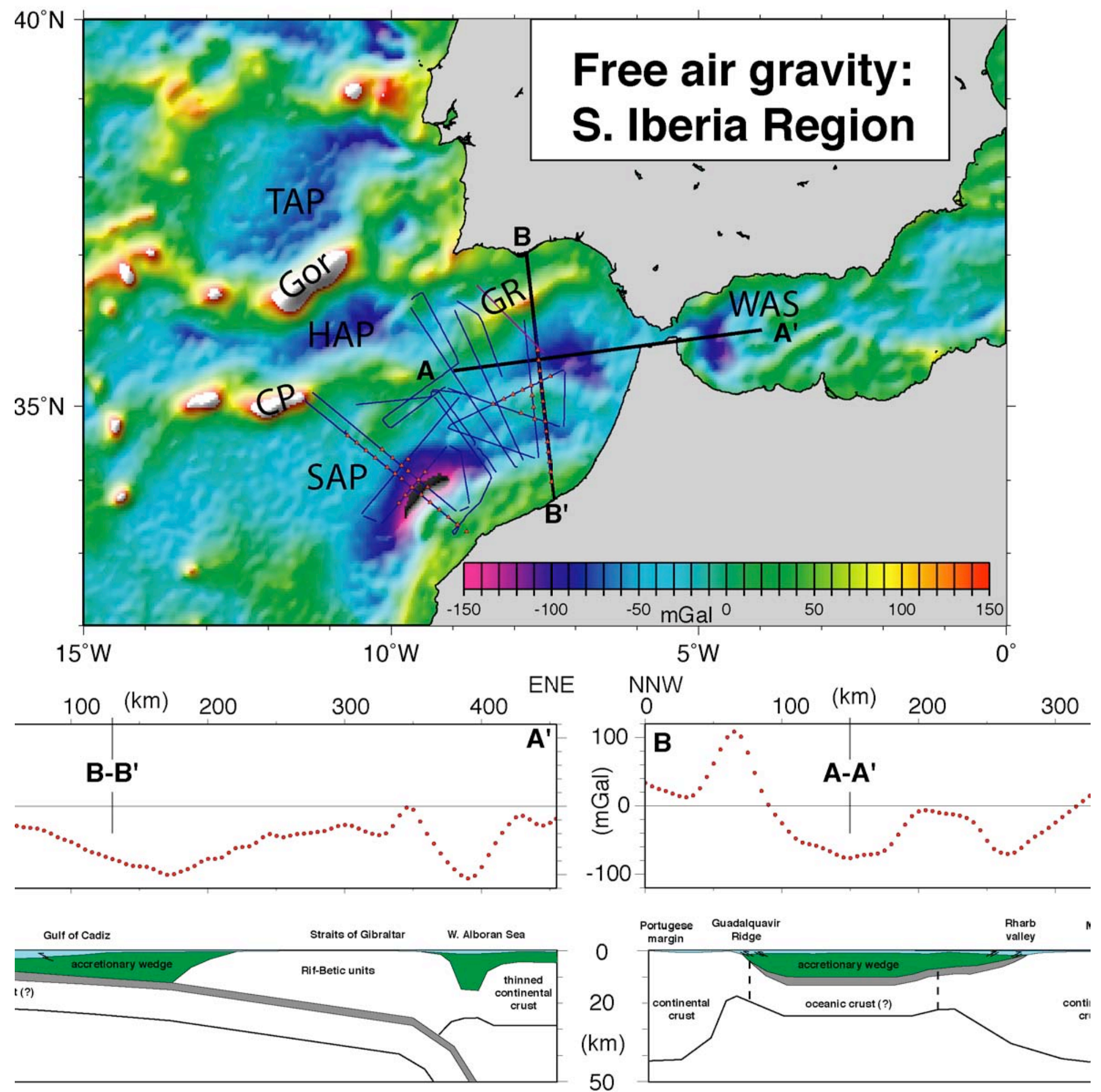
approx.scaling. $1 \mathrm{~cm}$ (model) $=2 \mathrm{~km}$ (nature)
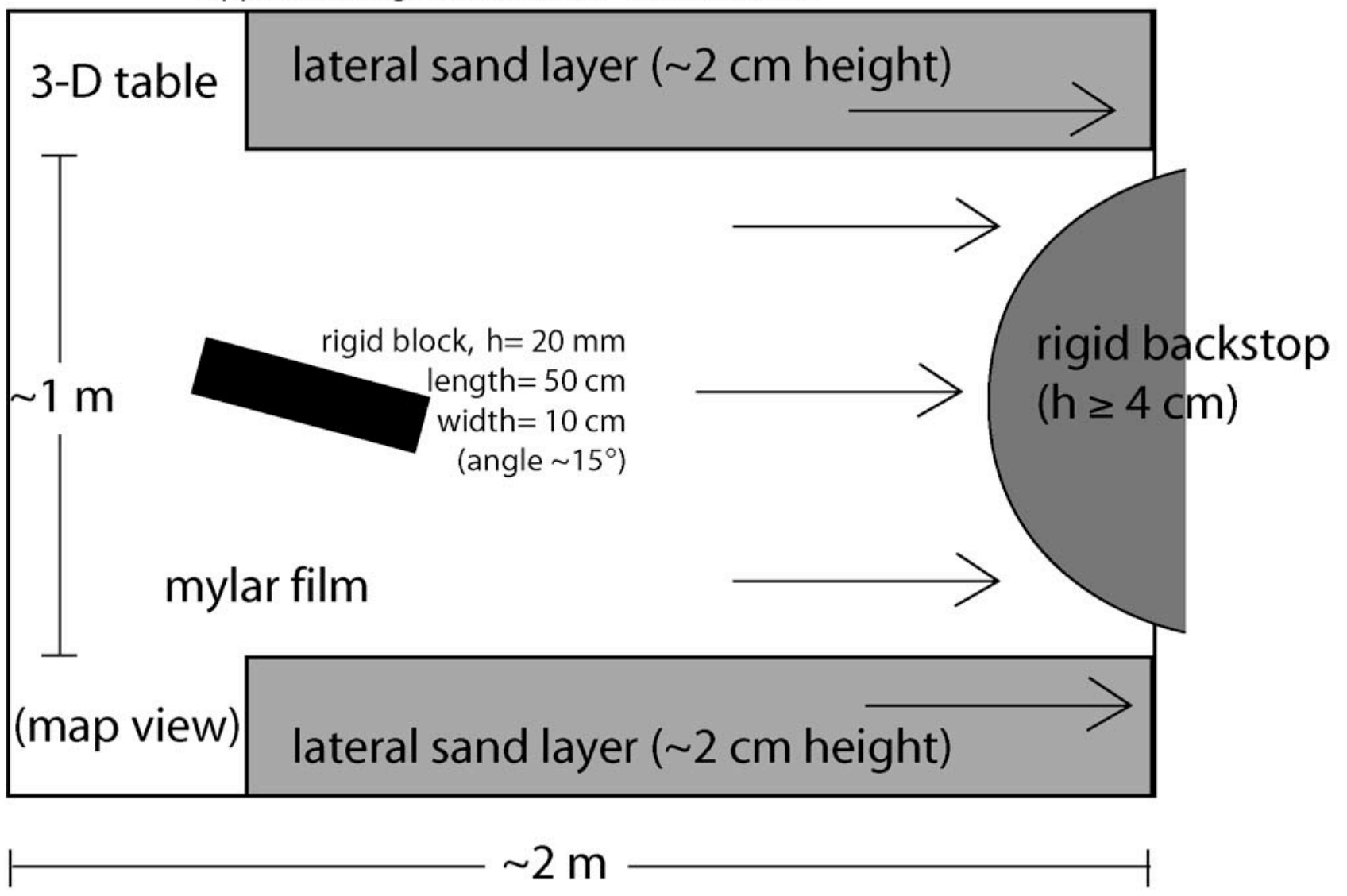

$1 \mathrm{~mm}$ fine, colored, cohesive, powder

$1 \mathrm{~cm}$ sand

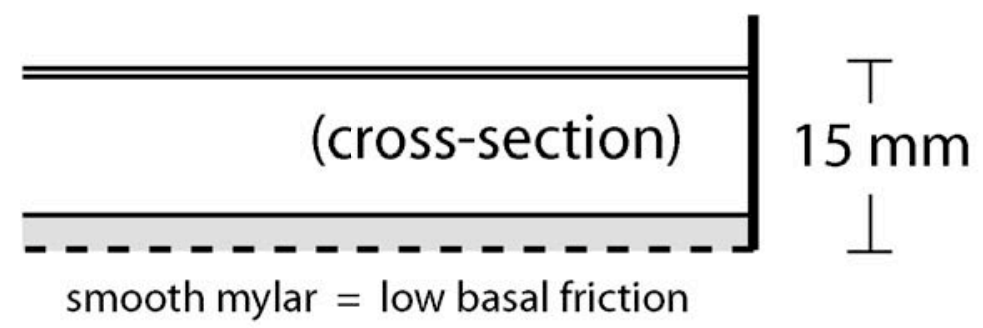

$4 \mathrm{~mm}$ glass beads

smooth mylar $=$ low basal friction 

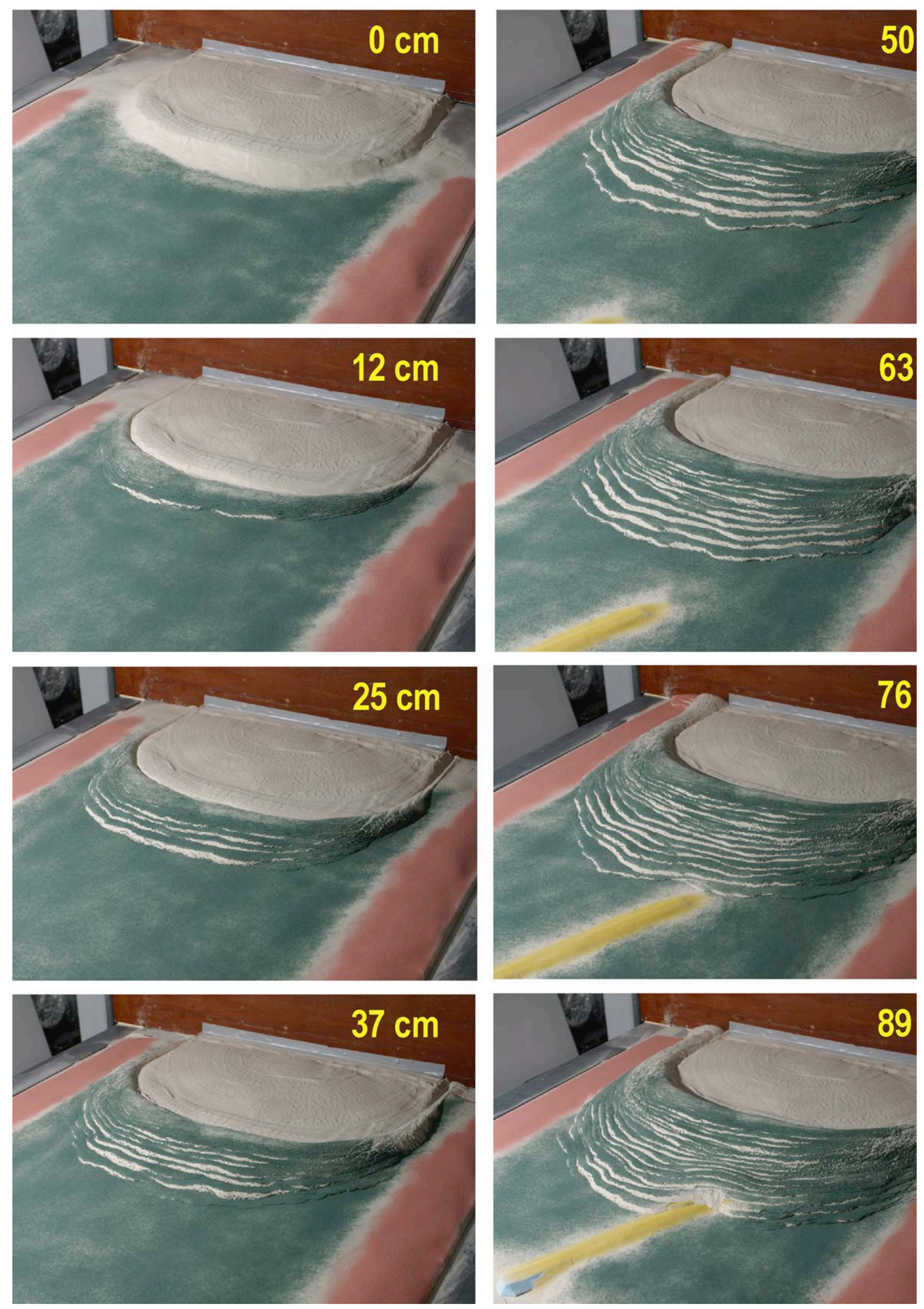

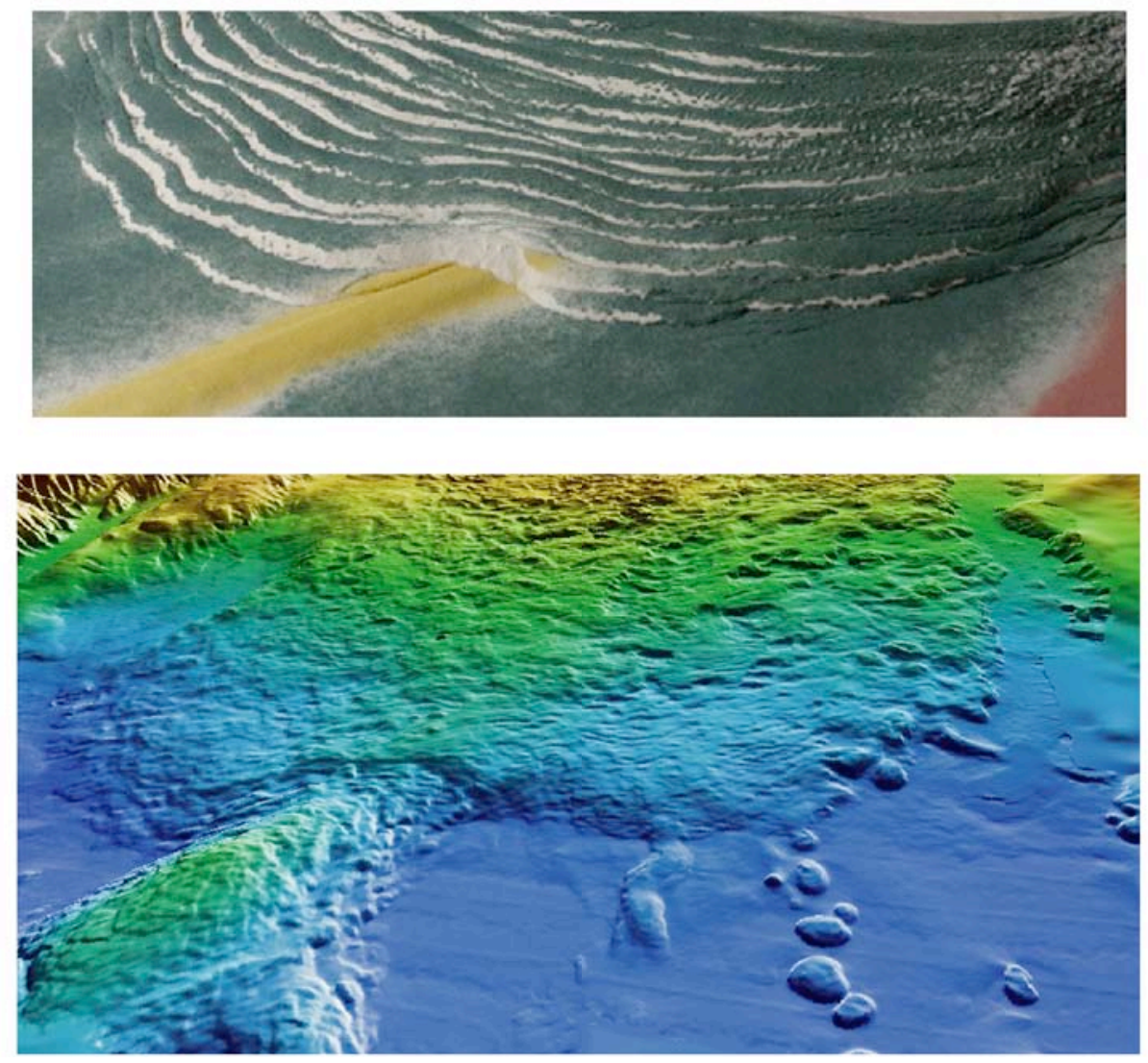


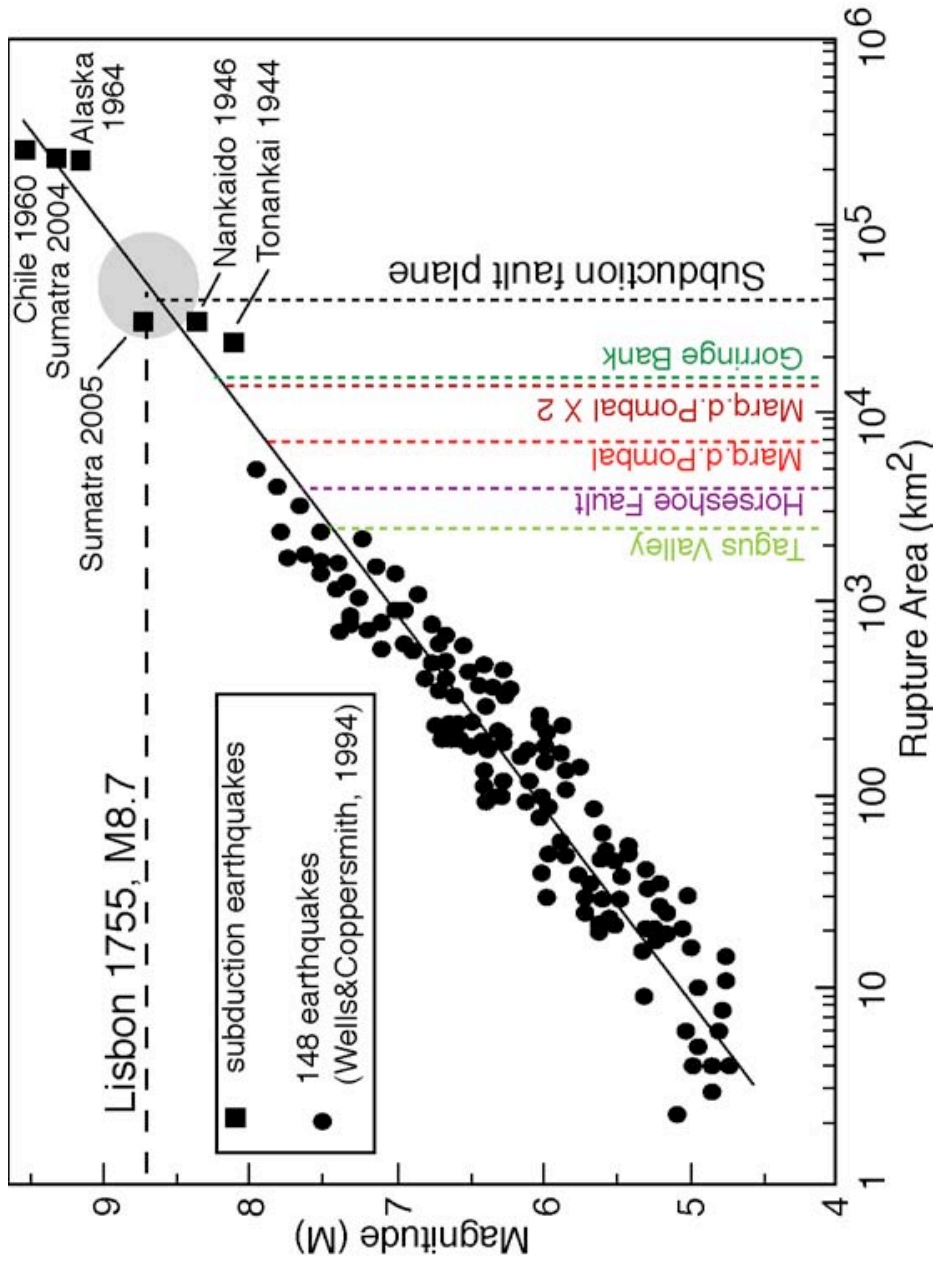

